\title{
EDITORIAL
}

\section{EL ROL DEL EDITOR Y LA VISIBILIDAD DEL CONOCIMIENTO EN LAS PUBLICACIONES CIENTÍFICAS SERIADAS}

\author{
ERNESTO L. RAVELO C. ${ }^{1 *}$ \\ ${ }^{1}$ Editor Revista Acta Colombiana de Psicología y asesor de Revista Med
}

\begin{abstract}
Una revista científica cualificada e indexada beneficia a la institución editora para posicionarse en la comunidad del conocimiento y particularmente en la visibilidad de la institución a nivel nacional $e$ internacional ante las organizaciones gubernamentales, el sector privado y la comunidad científica en general.

La mayor responsabilidad del Editor de una revista científica es mantener y vigilar permanente los procesos que conducen a elevar los indicadores de la calidad en los siguientes aspectos: a) el mejoramiento permanente de la calidad científica, b) las características editoriales, c) el establecimiento de actividades colaborativas, d) la visibilidad para el posicionamiento nacional e internacional, y e) la participación de autores extranjeros, entre otros.
\end{abstract}

Algunos factores que contribuyen al cumplimiento de la calidad científica son: a) la calidad académica de los miembros de los comités editorial y científico, con formación de maestría o doctorado y con producción intelectual activa publicada en revistas indexadas y con la participación de autores nacionales e internacionales reconocidos; b) la originalidad y calidad de los estudios $e$ investigaciones aceptadas para su publicación y c) la objetividad, rigurosidad y seriedad en los procesos de evaluación de los artículos.

En cuanto a los procesos de evaluación por pares expertos, ha sido una debilidad para la mayoría de las publicaciones científicas, particularmente en el ámbito latinoamericano y se ha caracterizado por algunas limitantes tales como: a) la demora en el tiempo transcurrido entre la asignación del documento al evaluador y la devolución del concepto, y b) el perfil de los árbitros, pues en la mayoría de los casos es difícil encontrar expertos que realicen una evaluación simultánea de los aspectos disciplinares, temáticos, metodológicos y estadísticos, y además que verifique la correspondencia y veracidad de las citas y referencias en los artículos.
Un proceso de evaluación con seriedad debe garantizar la objetividad y la rigurosidad, así como tener en cuenta diferentes momentos necesarios para la revisión y sugerencias al documento postulado para su posible publicación: a) inicia el proceso con una revisión previa de los artículos por parte del Editor; b) luego se remite a evaluación temática y en lo posible, metodológica y estadística, si así lo requiere; c) cuando no es posible lo anterior con un mismo evaluador, el documento se remite de forma independiente para su revisión temática, metodológica y estadística; d) se realiza la verificación y la correspondencia de citas y referencias; e) revisar el cumplimiento de la norma editorial propia de la revista; f) a continuación viene el proceso de revisión y redacción de los anteriores conceptos por parte del Editor y g) en caso de sugerencias, observaciones o correcciones se remite el concepto al autor para el cumplimiento de las mismas.

Con respecto a las características editoriales, se hace referencia a las exigencias de la condición de calidad editorial y se puede tomar como referente el Índice Bibliográfico Nacional que evalúa 18 características, tanto para la revista, el fascículo y el documento o artículo.

En cuanto a la disponibilidad de artículos se deben garantizar las diversas fuentes de consecución, entre ellas se pueden realizar gestiones para establecer convenios de actividades colaborativas, tanto nacionales como internacionales; por ejemplo entre instituciones, revistas, comunidades académicas, etc.; generar estrategias que contribuyan al establecimiento de redes de editores, grupos de investigación, árbitros, autores y establecer relaciones, no solamente para ganar visibilidad, sino para fomentar la cultura de la co-citación.

De otra parte, la visibilidad se logra a partir de la postulación de la revistas para que sean evaluadas $e$ indexadas en reconocidos sistemas de indexación 
y bases de datos internacionales, lo cual contribuye a la divulgación de los productos allí publicados. La inclusión en los sistemas de indexación y bases de datos internacionales tiene, entre otras, las siguientes ventajas: a) la publicación electrónica en texto completo y libre acceso permite dar mayor visibilidad a la institución editora de la revista, b) permite la internacionalización del conocimiento producto de los más destacados estudios de investigadores y de los artículos de autores invitados nacionales e internacionales que publican en la revista, c) se dispone de un espacio permanente para la socialización del conocimiento de quienes publican, tanto nacional como internacionalmente y d) la revista a la vez facilita la consulta y se convierte en fuente de referencia para la comunidad académica en general. 


\title{
EDITORIAL
}

\section{THE ROLE OF THE EDITOR AND THE VISIBILITY OF KNOWLEDGE IN SCIENTIFIC SERIAL PUBLICATIONS}

\author{
ERNESTO L. RAVELO C.* \\ Editor of Colombian Acta of Psychology Journal and assessor of Med Journal
}

\begin{abstract}
A qualified indexed scientific journal offers benefits to the publishing institution through positioning it in the knowledge community and particularly in the visibility of the institution to national and international governmental organizations, private sector and the scientific community in general.
\end{abstract}

The major responsibility of the Editor of a scientific journal is to maintain and permanently scrutinise the processes that lead to increase the quality indicators in the following aspects: a) the permanent improvement of scientific quality, b) editorial features, c) the establishment of collaborative activities, d) visibility to the national and international positioning, and e) participation of foreign authors, among others.

Some factors that contribute to the fulfillment of the scientific quality are: a) the academic quality of the members of the editorial and scientific committees, with master's or doctoral training and active intellectual production published in indexed journals and with the participation of national and international recognised authors, b) the originality and quality of the studies and research papers accepted for publication, c) the fairness, thoroughness and seriousness in the process of articles evaluations.

As for the peer review process - done by experts, this has been a weakness for most scientific publications, particularly in Latin America where it has been characterised by limitations such as: a) The delay in time between the allocation of the document to the assessor and the return of the concept, b) the profile of the referees, since in most cases it is difficult to find experts able to conduct a simultaneous evaluation of disciplinary issues, thematic, methodological and statistical, and also that verify the correspondence and accuracy of quotations and references in the articles.
A serious evaluation process should ensure the objectivity and thoroughness, as much as it should look to comply with an appropriate duration time needed for the review and suggestions of the document proposed for publication: a) the process starts with a prior review of articles by the Editor; $b$ ) then refers to thematic evaluation and, if possible, methodological and statistical, if it is required; c) when the above is not possible with a single evaluator, the document is to be submitted separately for thematic, methodological and statistical review; d) verification is performed together with the correspondence of quotations and references; e) review compliance of the submitted article with the editorial policy; f) this is followed by the reviewing and drafting of the above mentioned concepts by the Editor and g) in case of suggestions, comments or corrections, the concept is send to the author for him to comply with them.

With regard to editorial features, it should refer to the demands of editorial quality and conditions, and it can be taken as a reference the National Bibliographic Index which evaluates 18 features for the magazine, the fascicle and the document or article.

Regarding the availability of articles, several sources must be guaranteed, among them the establishment of agreements for collaborative activities, both national and international; for example concurrence between institutions, journals, or academic communities, etc; strategies should be generated, that contribute to the establishment of networks of publishers, research groups, referees, authors and establishment of relationships, not only to gain visibility, but to promote a culture of co-citation.

Furthermore, the visibility is achieved from the submission of the journal to be evaluated and in- 
dexed in recognised index systems and international databases, which contributes to the diffusion of the products published there. Inclusion in indexing systems and international databases has, among others, the following advantages: a) the full-text electronic publishing and free access allowing better visibility to the institution beget the journal, b) allows the internationalisation of knowledge produced by the most prominent researchers and the articles written by invited national and international authors who are publishing in the journal, c) creates a permanent space for the socialisation of knowledge of the publishers, both national and internationally, and d) the journal in turn facilitates consultation and becomes a source of reference for the academic community in general. 


\title{
EDITORIAL
}

\section{O PAPEL DO EDITOR E DA VISIBILIDADE DE SABERES EM PUBLICAÇÕES CIENTÍFICAS SERIADAS}

\author{
ERNESTO L. RAVELO C. ${ }^{* *}$ \\ ${ }^{1}$ Editor do Jornal Acta Colombiana de Psicologia e orientador Med Jornal
}

\begin{abstract}
Uma revista científica qualificada e indexada benefícia á instituição editora para o posicionamento na comunidade do conhecimento e em particular na visibilidade da instituição nacional e internacional nas organizações não governamentais, do setor privado $e$ da comunidade científica em geral.

A principal responsabilidade do editor de uma revista científica é a de manter e acompanhar permanentemente os processos que levam a maiores indicadores de qualidade nos seguintes aspectos: a) a melhoramento permanente da qualidade científica, b) as características editoriais, c) o estabelecimento de atividades colaborativas, d) a visibilidade para o posicionamento nacional e internacional, e) a participação de autores estrangeiros, entre outros.
\end{abstract}

Alguns fatores que contribuem para o cumprimento da qualidade científica são: a) a qualidade acadêmica dos membros dos comitês científicos e editoriais, com mestrado ou doutoramento e produção intelectual ativa publicados em revistas indexadas e com a participação de renomados autores nacionais e internacionais; b) a originalidade e qualidade dos estudos e pesquisas aceitos para publicação e c) o rigor, objectividade $e$ seriedade no processo de avaliação dos artigos.

Quanto ao processo de revisão pelos pares - os especialistas, tem sido um ponto fraco para a maioria das publicações científicas, particularmente na América Latina e caracterizado por certas limitações, tais como: a) o atraso no tempo entre a atribuição do documento para o avaliador eo retorno do conceito, e b) o perfil dos árbitros, pois na maioria dos casos é difícil encontrar especialistas para realizar uma avaliação simultânea de problemas disciplinares, temática, metodológica e estatística, e também para verificar a correspondência e a exatidão das citações e referências nos artigos.
Um processo de avaliação séria deve assegurar a objectividade e rigor, bem como olhar para diferentes tempos necessários para a avaliação e sugestões para o documento proposto para publicação: a) o processo se inicia com uma revisão prévia dos estatutos pelo Editor; b) em seguida, são encaminhados para avaliação do tema, a metodologia $e$ as estatísticas, se necessário; c) quando não for possível, esta com o mesmo assessor, o documento é apresentado separadamente para análise temática, metodológica e estatística; d) verificação é realizada e a correspondência de citações e referências; e) Verificar o cumplimento da política editorial da própria revista; f) Depois vem o processo de revisão e elaboração dos conceitos pelo Editor e g) em caso de sugestões, comentários ou correções o conceito refere-se ao autor.

Com relação aos aspectos editoriais, é feita referência às exigências da condição de qualidade editorial e pode ser tomado como uma referência o Índice Bibliográfico Nacional que avalia 18 características, tanto para a revista, a especificação eo documento ou artigo.

Quanto à disponibilidade de itens devem ser garantidas as diferentes fontes de aquisição, entre eles podem tomar medidas para estabelecer acordos para atividades de colaboração, nacionais e internacionais, por exemplo, entre as instituições, revistas, acadêmicos, etc.; gerar estratégias que contribuam para o estabelecimento de redes de editoras, grupos de pesquisa, os árbitros, os autores e estabelecer relacionamentos, não só para ganhar visibilidade, mas para promover uma cultura de co-citação.

Além disso, a visibilidade é alcançada a partir da aplicação dos periódicos a serem avaliados e indexados nos sistemas de índice reconhecido e bases de dados internacionais, que contribui para a difusão 
dos produtos nele publicado. Inclusão em sistemas de indexação e bancos de dados internacional, entre outras, as seguintes vantagens: a) o texto integral da edição electrónica e permitindo o livre acesso, melhor visibilidade à instituição, editor da revista, b) permite a internacionalização do conhecimento do produto dos estudos de investigação $e$ artigos de autores convidados nacionais e internacionais que publicam na revista, c) há um espaço permanente para a socialização do conhecimento dos cartazes, tanto a nível nacional e internacional e d) a revista, por sua vez facilita a consulta e se torna uma fonte de referência para a comunidade acadêmica em general. 